\title{
Aeromicrobium tamlense sp. nov., isolated from dried seaweed
}

\author{
Soon Dong Lee ${ }^{1}$ and Se Jae Kim² \\ ${ }^{1}$ Department of Science Education, Cheju National University, Jeju 690-756, Republic of Korea \\ ${ }^{2}$ Department of Life Science, Cheju National University, Jeju 690-756, Republic of Korea
}

Correspondence

Soon Dong Lee

sdlee@cheju.ac.kr

\begin{abstract}
A Gram-positive, non-motile, rod-shaped actinomycete strain, designated SSW1-57 ${ }^{\top}$, was isolated from a dried seaweed sample from the coast of Jeju Island, Republic of Korea and subjected to a polyphasic taxonomic study. A neighbour-joining tree based on 16S rRNA gene sequences showed that the organism was related to members of the family Nocardioidaceae and formed a separate branch at the base of a taxon encompassing members of the genus Aeromicrobium, whereas it occupied an intermediate position between Aeromicrobium alkaliterrae-Aeromicrobium marinum and Aeromicrobium erythreum-Aeromicrobium fastidiosum clusters in maximum-parsimony and maximum-likelihood trees. The phylogenetic association of the isolate with the genus Aeromicrobium was supported by the following chemotaxonomic properties: LL-diaminopimelic acid in the peptidoglycan, MK-9 $\left(\mathrm{H}_{4}\right)$ as the major menaquinone and major fatty acids cis-9-octadecenoic acid, hexadecanoic acid, 10-methyl octadecanoic acid and 2-hydroxy hexadecanoic acid. The polar lipid profile contained phosphatidylinositol, diphosphatidylglycerol and phosphatidylglycerol. Levels of 16S rRNA gene sequence similarity between the novel organism and the type strains of the four recognized Aeromicrobium species were in the range 96.5-96.7\%. On the basis of phylogenetic analyses and phenotypic data, it is proposed that the organism should be classified as representing a novel species of the genus Aeromicrobium, with the name Aeromicrobium tamlense sp. nov. The type strain is SSW1-57 $\left(=\mathrm{JCM} 13811^{\top}=\right.$ NRRL B-24466 $\left.{ }^{\top}\right)$.
\end{abstract}

The genus Aeromicrobium was first proposed by Miller et al. (1991) to accommodate an aerobic, Gram-positive, motile actinomycete that showed coccoid or rod-shaped morphology; its description was emended recently by Yoon et al. (2005). Currently, the genus comprises four species, Aeromicrobium alkaliterrae (Yoon et al., 2005), Aeromicrobium erythreum (Miller et al., 1991), the type species of the genus, Aeromicrobium fastidiosum (Tamura \& Yokota, 1994) and Aeromicrobium marinum (Bruns et al., 2003), which were isolated from environmental samples such as soils and seawater. Comparative studies of 16S rRNA gene sequences showed that the genus Aeromicrobium was phylogenetically related to members of the genera Marmoricola and Nocardioides within the radiation of the family Nocardioidaceae (Stackebrandt et al., 1997; Urzì et al., 2000; Yoon et al., 2005). In this paper, we describe the taxonomic status of a novel Aeromicrobium strain that was isolated from dried seaweed collected from a beach.

\footnotetext{
The GenBank/EMBL/DDBJ accession number for the 16S rRNA gene sequence of strain SSW $1-57^{\top}$ is DQ411541.

A table detailing the cellular fatty acid content of strain SSW $1-57^{\top}$ and related species of the genus Aeromicrobium is available as supplementary material in IJSEM Online.
}

During an investigation of the genetic diversity of polysaccharide-producing marine bacteria, strain SSW1$57^{\mathrm{T}}$ was isolated from dried seaweed collected from Samyang beach in Jeju Island, Korea, and subjected to morphological, cultural, physiological and chemotaxonomic characterization, in addition to 16S rRNA gene sequence studies. A dried seaweed sample $(1 \mathrm{~g})$ was placed into a sterile plastic tube containing $9 \mathrm{ml}$ sterile distilled water. After mixing for $30 \mathrm{~min}$ using a tube rotator, aliquots $(100 \mu \mathrm{l})$ of serial dilutions of the sample were transferred onto plates of isolation medium (SC-SW agar) containing $10 \mathrm{~g}$ soluble starch, $0.3 \mathrm{~g}$ casein, $2 \mathrm{~g} \mathrm{KNO}_{3}, 2 \mathrm{~g} \mathrm{NaCl}, 0.02 \mathrm{~g}$ $\mathrm{CaCO}_{3}, 0.05 \mathrm{~g} \mathrm{MgSO}_{4} .7 \mathrm{H}_{2} \mathrm{O}, 0.01 \mathrm{~g} \mathrm{FeSO}_{4} .7 \mathrm{H}_{2} \mathrm{O}$ and $18 \mathrm{~g}$ agar in a mixture of $600 \mathrm{ml}$ natural seawater and $400 \mathrm{ml}$ distilled water $(\mathrm{pH} 7.2)$. After incubation at $30^{\circ} \mathrm{C}$ for 14 days, a colony from one plate was subcultivated on YESW agar ( 4 g yeast extract, 10 g malt extract, 4 g glucose and $18 \mathrm{~g}$ agar in a mixture of $600 \mathrm{ml}$ natural seawater and $400 \mathrm{ml}$ distilled water; $\mathrm{pH} \mathrm{7.2)}$. The pure culture was maintained at -20 and $-80{ }^{\circ} \mathrm{C}$ in $20 \%$ glycerol supplemented with $60 \%(\mathrm{v} / \mathrm{v})$ natural seawater.

Chromosomal DNA was extracted and purified by using a Wizard Genomic DNA Purification kit (Promega), according to the manufacturer's instructions. PCR amplification 
and sequencing of the 16S rRNA gene were performed as described previously (Lee et al., 2000). The CLUSTAL_X program (Thompson et al., 1997) was used to align an almost-complete 16S rRNA gene sequence of strain SSW1$57^{\mathrm{T}}$ (1406 nt; determined in this study) with corresponding sequences of members of the family Nocardioidaceae and related genera. Phylogenetic analyses were carried out using several tree-making algorithms contained in the PHYLIP package (Felsenstein, 1993). Bootstrap analysis (Felsenstein, 1985) was performed to evaluate the reliability of the tree topology. A total of 1333 unambiguous, aligned positions present in all strains between positions 59 and 1431 (Escherichia coli numbering; Brosius et al., 1978) were used for the final tree construction. A neighbour-joining tree based on 16S rRNA gene sequences (Fig. 1) showed that strain SSW $1-57^{\mathrm{T}}$ belongs to the family Nocardioidaceae and formed a peripheral branch in the Aeromicrobium cluster, supported by a bootstrap value of $100 \%$. In trees constructed using maximum-parsimony and maximumlikelihood methods, strain SSW $1-57^{\mathrm{T}}$ occupied an intermediate position between the $A$. alkaliterrae- $A$. marinum and $A$. erythreum-A. fastidiosum branches. The levels of $16 \mathrm{~S}$ rRNA gene sequence similarity between strain SSW1-57 and its phylogenetic relatives were $96.7 \%$ (with $A$. erythreum) and $96.5 \%$ (with A. alkaliterrae, A. fastidiosum and A. marinum). Sequence similarities between strain SSW $1-57^{\mathrm{T}}$ and other members of the family Nocardioidaceae were less than $94.2 \%$.

For analysis of polar lipids, menaquinones and the cell wall, strain SSW $1-57^{\mathrm{T}}$ was cultivated in YE-SW broth for 3 days at $30^{\circ} \mathrm{C}$ and analysed as described previously (Lee, 2006). The DNA G+C content of strain SSW $1-57^{\mathrm{T}}$ was $72.7 \mathrm{~mol} \%$. The isolate contained LL-diaminopimelic acid as the diagnostic diamino acid in the cell wall [wall chemotype I sensu Lechevalier \& Lechevalier (1970)]. The

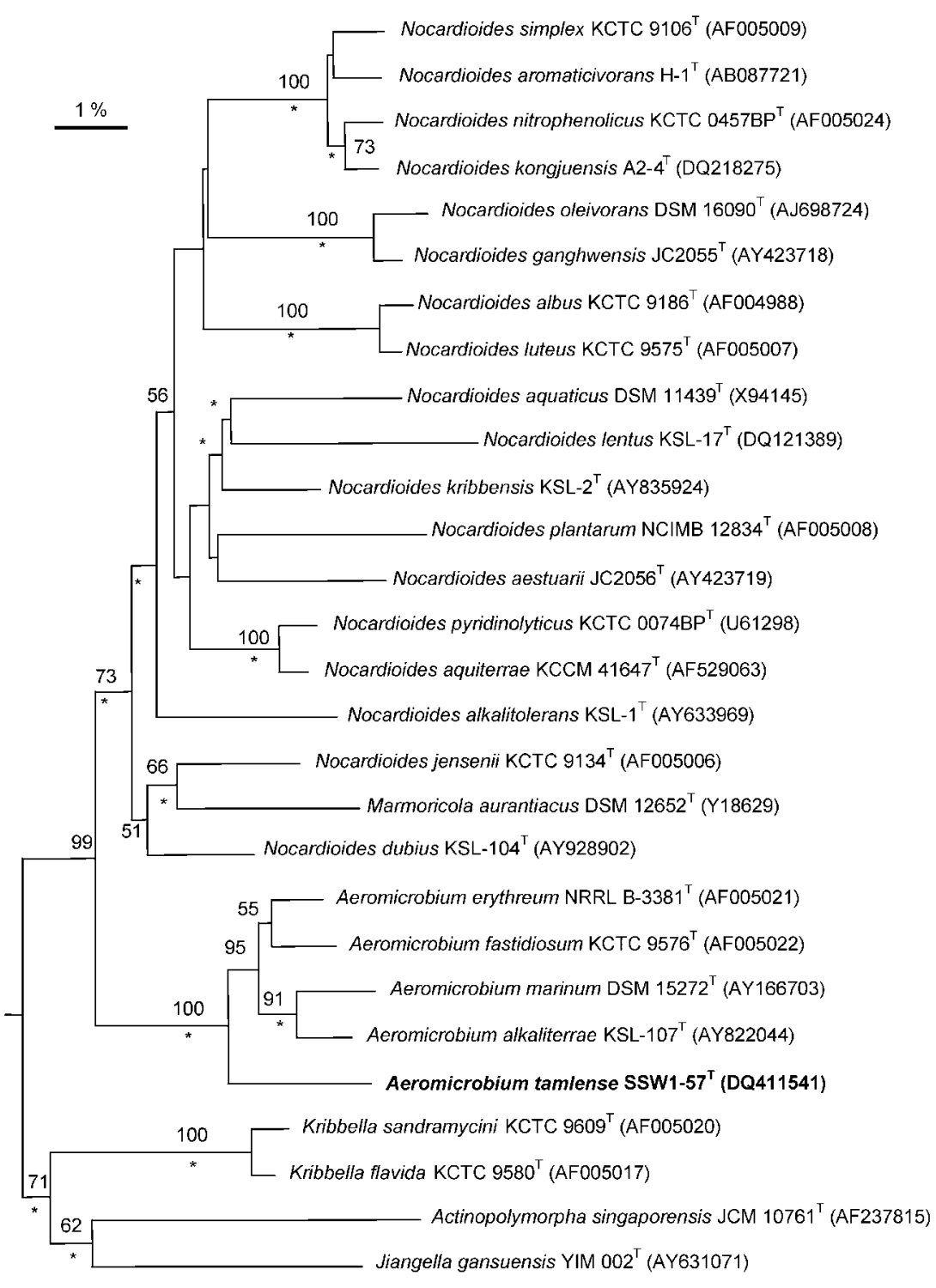

Fig. 1. Neighbour-joining tree based on 16S rRNA gene sequences showing the phylogenetic position of strain SSW $1-57^{\top}$ within the radiation encompassing members of the family Nocardioidaceae. The tree was reconstructed from evolutionary distances calculated using the Jukes-Cantor coefficient (Jukes \& Cantor, 1969). Streptomyces griseus was used as an outgroup (not shown). Asterisks indicate branches that were also found in maximum-likelihood and maximum-parsimony trees. Numbers at nodes are percentage bootstrap values based on a neighbour-joining analysis of 1000 replications (only values greater than $50 \%$ are shown). Bar, 1 nucleotide substitution per 100 nucleotides. 
predominant isoprenoid quinone was tetrahydrogenated menaquinone with nine isoprene units $\left[\mathrm{MK}-9\left(\mathrm{H}_{4}\right)\right]$, indicating that strain $S S W 1-57^{\mathrm{T}}$ contained a type of menaquinone that was different from that found in its phylogenetic neighbours Marmoricola and Nocardioides (Park et al., 1999; Urzì et al., 2000). Mycolic acids were not present. The phospholipid profile comprised phosphatidylinositol, diphosphatidylglycerol and phosphatidylglycerol [phospholipid type I pattern as defined by Lechevalier et al. (1981)]. Preparation and analysis of the cellular fatty acid methyl esters were performed using the Sherlock Microbial Identification System (version 6.0; MIDI), according to the instructions of the manufacturer. Strain SSW $1-57^{\mathrm{T}}$ was grown for 3 days at $30^{\circ} \mathrm{C}$ on trypticase soy broth (Difco) supplemented with Bacto agar (Difco). The cellular fatty acid profile of strain SSW $1-57^{\mathrm{T}}$ was characterized by the presence $(\geqslant 1.0 \%)$ of $\mathrm{C}_{18: 1} \omega 9 c(47.2 \%), \mathrm{C}_{16: 0}$ (13.8\%), $\mathrm{C}_{18: 0}(13.6 \%)$ 10-methyl $\mathrm{C}_{18: 0}(8.7 \%), \mathrm{C}_{16: 0} 2$ $\mathrm{OH}(6.8 \%), \mathrm{C}_{17: 0}(1.8 \%), \mathrm{C}_{16: 1} \omega 9 c(1.6 \%), \mathrm{C}_{12: 0}(1.4 \%)$, $\mathrm{C}_{17: 0} 2-\mathrm{OH}(1.1 \%), \mathrm{C}_{14: 0}(1.0 \%)$ and $\mathrm{C}_{15: 0}(1.0 \%)$ acids. The major fatty acids were consistent with those of members of the genus Aeromicrobium (Park et al., 1999; Bruns et al., 2003; Yoon et al., 2005), as shown in Supplementary Table S1 in IJSEM Online. Thus, the chemotaxonomic markers, except for the phospholipid composition, were in agreement with the phylogenetic clustering of the novel isolate with the genus Aeromicrobium. The difference in polar lipids between the isolate and A. erythreum and A. fastidiosum, which contained phosphatidylethanolamine (Tamura \& Yokota, 1994), suggests that the presence/ absence of phospholipids with amino groups could be one phenotypic characteristic that differentiates the novel isolate from the two species. To date, the phospholipid compositions of A. alkaliterrae and A. marinum have not been reported.

Morphological and physiological characteristics were investigated using YE-SW agar at $30^{\circ} \mathrm{C}$. Cell morphology and motility were observed using phase-contrast and transmission electron microscopy with 3-day-old cultures. Colony pigmentation was observed visually and recorded using 5day-old cultures on YE-SW agar at $30^{\circ} \mathrm{C}$. The Gramreaction was determined by using a Gram-stain kit (bioMérieux), following the instructions of the manufacturer. Oxidation of $N, N, N^{\prime}, N^{\prime}$-tetramethyl-p-phenylenediamine was used to determine oxidase activity. Catalase activity was determined using $3 \%(\mathrm{v} / \mathrm{v}) \mathrm{H}_{2} \mathrm{O}_{2}$ solution. Growth at a range of temperatures $\left(4-45^{\circ} \mathrm{C}\right)$ was tested using YE-SW agar. Growth in various $\mathrm{NaCl}$ concentrations was studied using ISP 2 medium (Shirling \& Gottlieb, 1966). $\mathrm{NaCl}$ was added to the basal medium at final concentrations of $0-9,10$ and $15 \%(\mathrm{w} / \mathrm{v})$. The $\mathrm{pH}$ range for growth was determined on YE-SW agar adjusted to $\mathrm{pH}$ 4.1-12.1 (at intervals of $1.0 \mathrm{pH}$ units). The $\mathrm{pH}$ of the medium was adjusted prior to sterilization by addition of $6 \mathrm{M} \mathrm{HCl}$ or $10 \mathrm{M} \mathrm{NaOH}$. Decomposition of hypoxanthine, DL-tyrosine and xanthine was examined as described by Gordon et al. (1974). Hydrolysis of casein, gelatin and starch was tested as described by MacFaddin (1980). The ability to utilize a variety of substrates as sole carbon and energy sources was tested using ISP 9 medium (Shirling \& Gottlieb, 1966), with each filter-sterilized carbon source being used at a final concentration of $1 \%(\mathrm{w} / \mathrm{v})$ for carbohydrates and alcohols and $0.1 \%(\mathrm{w} / \mathrm{v})$ for organic acids. Strain $\mathrm{SSW} 1-57^{\mathrm{T}}$ was grown on YE-SW agar at $30^{\circ} \mathrm{C}$ for 3 days and the cells were then scraped from the agar surface with a cotton swab. The cells were washed and resuspended in sterile distilled water before being used. Other physiological and biochemical properties were tested using API 20E and API ZYM systems (bioMérieux), according to the instructions of the manufacturer. Morphological, physiological and biochemical properties are given in Table 1 and the species description.

On the basis of phenotypic data and phylogenetic analyses, it is suggested that the isolate should be classified as representing a novel species of the genus Aeromicrobium, for which we propose the name Aeromicrobium tamlense sp. nov., with strain SSW $1-57^{\mathrm{T}}$ as the type strain.

\section{Description of Aeromicrobium tamlense sp. nov.}

Aeromicrobium tamlense (tam.len'se. N.L. neut. adj. tamlense of Tamla, the old name of Jeju, Republic of Korea, the site of isolation of the type strain).

Aerobic, oxidase-negative and catalase-positive. Cells are Gram-positive irregular rods ranging in size from $0.4-0.6 \times 0.8-1.2$ to $0.5 \times 3.8-4.8 \mu \mathrm{m}$. Non-motile. Branching or mycelial form does not occur. Endospores are not formed. Colonies are circular, smooth, convex, yellow and $0.6-0.8 \mathrm{~mm}$ in diameter after incubation for 5 days on YE-SW agar at $30^{\circ} \mathrm{C}$. Temperature range for growth is $10-42{ }^{\circ} \mathrm{C}$, with optimum growth at $30^{\circ} \mathrm{C}$. No growth occurs at 4 or $45^{\circ} \mathrm{C}$. Growth occurs at pH 5.1-10.1, with optimum growth at $\mathrm{pH}$ 7.1. Growth occurs in the presence of $0-5 \% \mathrm{NaCl}$. Nitrate is not reduced to nitrite. Gelatin liquefaction is observed. Aesculin is hydrolysed, but not casein. $\mathrm{H}_{2} \mathrm{~S}$ and indole are not produced. Hypoxanthine is decomposed, but not DL-tyrosine or xanthine. Urease activity is not detected. In API 20E tests, the following enzymic activities are not detected: arginine dihydrolase, lysine decarboxylase, ornithine decarboxylase and tryptophan deaminase. Voges-Proskauer reaction is weakly positive. Acetate, D-cellobiose, dextran, D-fructose, Dgalactose, D-glucose, D-lactose, malate, maltose, D-mannose, methyl $\alpha$-D-glucoside, L-ribose, succinate, sucrose, Dtrehalose and glycerol are utilized as sole carbon and energy sources. The following carbon sources are not utilized: D-arabinose, L-arabinose, benzoate, citrate, formate, inulin, D-melezitose, methyl $\alpha$-D-mannoside, D-raffinose, Lrhamnose, salicin, L-sorbose, tartrate, D-xylose, adonitol, 2,3-butanediol, D-dulcitol, meso-erythritol, myo-inositol, Dmannitol, 1,2-propanediol, D-sorbitol and D-xylitol. In API ZYM tests, alkaline phosphatase, leucine arylamidase, acid phosphatase and $\alpha$-glucosidase are positive. Esterase (C4), lipase (C14), valine arylamidase, cystine arylamidase, 
Table 1. Phenotypic characteristics that differentiate strain $S S W 1-57^{\top}$ from its phylogenetic relatives

Taxa: 1, strain SSW1-57' ; 2, A. alkaliterrae (data from Yoon et al., 2005); 3, A. erythreum (Miller et al., 1991; Tamura \& Yokota, 1994); 4, A. fastidiosum (Collins \& Stackebrandt, 1989; Tamura \& Yokota, 1994); 5, A. marinum (Bruns et al., 2003). +, Positive; W, weakly positive; - , negative; ND, not determined.

\begin{tabular}{|c|c|c|c|c|c|}
\hline Characteristic & 1 & 2 & 3 & 4 & 5 \\
\hline Cell morphology & Irregular rods & Rods, cocci & Irregular rods, cocci & Rods, cocci & Rods \\
\hline Motility & - & - & - & + & - \\
\hline \multicolumn{6}{|l|}{ Growth at: } \\
\hline $42^{\circ} \mathrm{C}$ & + & - & - & - & - \\
\hline $10^{\circ} \mathrm{C}$ & + & + & - & + & + \\
\hline \multicolumn{6}{|l|}{ Utilization of: } \\
\hline L-Arabinose & - & + & + & + & - \\
\hline Citrate & - & - & $\mathrm{ND}$ & + & - \\
\hline D-Fructose & + & - & + & + & - \\
\hline D-Glucose & + & + & + & $\mathrm{ND}$ & - \\
\hline Maltose & + & + & - & - & - \\
\hline D-Mannose & + & - & - & + & - \\
\hline Salicin & - & + & - & $\mathrm{ND}$ & $\mathrm{ND}$ \\
\hline Sucrose & + & + & + & ND & - \\
\hline D-Xylose & - & - & + & ND & - \\
\hline \multicolumn{6}{|l|}{ Hydrolysis of: } \\
\hline Aesculin & + & - & + & $\mathrm{ND}$ & $\mathrm{ND}$ \\
\hline Casein & - & + & + & + & - \\
\hline \multicolumn{6}{|l|}{ API ZYM: } \\
\hline Acid phosphatase & + & + & + & + & - \\
\hline Alkaline phosphatase & + & - & - & + & - \\
\hline Esterase (C4) & - & + & + & + & + \\
\hline$\alpha$-Glucosidase & + & + & + & + & - \\
\hline Trypsin & $\mathrm{w}$ & - & - & - & - \\
\hline Phospholipids ${ }^{\star}$ & DPG, PG, PI & ND & DPG, PE, PG & DPG, PE, PG & $\mathrm{ND}$ \\
\hline DNA G $+\mathrm{C}$ content $(\mathrm{mol} \%)$ & 72.7 & 71.5 & $71-73$ & $71-72$ & 70.6 \\
\hline
\end{tabular}

${ }^{\star}$ DPG, Phosphatidylglycerol; PE, phosphatidylethanolamine; PG, phosphatidylglycerol; PI, phosphatidylinositol.

$\alpha$-chymotrypsin, $\alpha$-galactosidase, $\beta$-galactosidase, $\beta$-glucuronidase, $\beta$-glucosidase, $N$-acetyl- $\beta$-glucosaminidase, $\alpha$-mannosidase and $\alpha$-fucosidase are negative. The following are weakly positive: esterase lipase (C8), trypsin and naphtholAS-BI-phosphohydrolase. Predominant cellular fatty acids are $\mathrm{C}_{18: 1} \omega 9 c, \mathrm{C}_{16: 0}, 10$-methyl $\mathrm{C}_{18: 0}, \mathrm{C}_{18: 0}$ and $\mathrm{C}_{16: 0} 2-\mathrm{OH}$. Polar lipids comprise phosphatidylinositol, diphosphatidylglycerol and phosphatidylglycerol.

The $\mathrm{G}+\mathrm{C}$ content of the DNA of the type strain is $72.7 \mathrm{~mol} \%$. The type strain is strain SSW $1-57^{\mathrm{T}}$ (= JCM $13811^{\mathrm{T}}=$ NRRL B-24466 ${ }^{\mathrm{T}}$ ), which was isolated from dried seaweed.

\section{Acknowledgements}

This work was supported by the 21C Frontier Microbial Genomics and Application Center Program, Ministry of Science and Technology, Republic of Korea and by grant no. BDM 0100211 from the Strategic National R\&D Programme through the Genetic Resources and Information Network Center funded by the Korean Ministry of
Science and Technology. The authors are indebted to Seong Hae Seo for the analysis of cellular fatty acids and Dong Wan Lee for determination of DNA G + C content.

\section{References}

Brosius, J., Palmer, M. L., Kennedy, P. J. \& Noller, H. F. (1978). Complete nucleotide sequence of a $16 \mathrm{~S}$ ribosomal RNA gene from Escherichia coli. Proc Natl Acad Sci U S A 75, 4801-4805.

Bruns, A., Philipp, H., Cypionka, H. \& Brinkhoff, T. (2003). Aeromicrobium marinum sp. nov., an abundant pelagic bacterium isolated from the German Wadden Sea. Int J Syst Evol Microbiol 53, 1917-1923.

Collins, M. D. \& Stackebrandt, E. (1989). Molecular taxonomic studies on some LL-diaminopimelic acid-containing coryneforms from herbage; description of Nocardioides fastidiosa sp. nov. FEMS Microbiol Lett 48, 289-293.

Felsenstein, J. (1985). Confidence limits on phylogenies: an approach using the bootstrap. Evolution 39, 783-791.

Felsenstein, J. (1993). PHYLIP (phylogeny inference package), version 3.5c. Department of Genome Sciences, University of Washington, Seattle, USA. 
Gordon, R. E., Barnett, D. A., Handerhan, J. E. \& Pang, C. H.-N. (1974). Nocardia coeliaca, Nocardia autotrophica, and the nocardin strain. Int J Syst Bacteriol 24, 54-63.

Jukes, T. H. \& Cantor, C. R. (1969). Evolution of protein molecules. In Mammalian Protein Metabolism, pp. 21-132. Edited by H. N. Munro. New York: Academic Press.

Lechevalier, M. P. \& Lechevalier, H. (1970). Chemical composition as a criterion in the classification of aerobic actinomycetes. Int J Syst Bacteriol 20, 435-443.

Lechevalier, M. P., Stern, A. E. \& Lechevalier, H. A. (1981). Phospholipids in the taxonomy of actinomycetes. Zentralbl Bakteriol Hyg Abt 1 Suppl 11, 111-116.

Lee, S. D. (2006). Nocardia jejuensis sp. nov., a novel actinomycete isolated from a natural cave on Jeju Island, Republic of Korea. Int J Syst Evol Microbiol 56, 559-562.

Lee, S. D., Kang, S.-O. \& Hah, Y. C. (2000). Hongia gen. nov., a new genus of the order Actinomycetales. Int J Syst Evol Microbiol 50, 191-199.

MacFaddin, J. F. (1980). Biochemical Tests for Identification of Medical Bacteria, 2nd edn. Baltimore: Williams \& Wilkins.

Miller, E. S., Woese, C. R. \& Brenner, S. (1991). Description of the erythromycin-producing bacterium Arthrobacter sp. strain NRRL B3381 as Aeromicrobium erythreum gen. nov., sp. nov. Int J Syst Bacteriol 41, 363-368.
Park, Y.-H., Yoon, J.-H., Shin, Y. K., Suzuki, K.-i., Kudo, T., Seino, A., Kim, H.-J., Lee, J.-S. \& Lee, S. T. (1999). Classification of 'Nocardioides fulvus' IFO 14399 and Nocardioides sp. ATCC 39419 in Kribbella gen. nov., as Kribbella flavida sp. nov. and Kribbella sandramycini sp. nov. Int J Syst Bacteriol 49, 743-752.

Shirling, E. B. \& Gottlieb, D. (1966). Methods for characterization of Streptomyces species. Int J Syst Bacteriol 16, 313-340.

Stackebrandt, E., Rainey, F. A. \& Ward-Rainey, N. L. (1997). Proposal for a new hierarchic classification system, Actinobacteria classis nov. Int J Syst Bacteriol 47, 479-491.

Tamura, T. \& Yokota, A. (1994). Transfer of Nocardioides fastidiosa Collins and Stackebrandt 1989 to the genus Aeromicrobium as Aeromicrobium fastidiosum comb. nov. Int J Syst Bacteriol 44, 608-611.

Thompson, J. D., Gibson, T. J., Plewniak, F., Jeanmougin, F. \& Higgins, D. G. (1997). The CLUSTAL_X windows interface: flexible strategies for multiple sequence alignment aided by quality analysis tools. Nucleic Acids Res 25, 4876-4882.

Urzì, C., Salamone, P., Schumann, P. \& Stackebrandt, E. (2000). Marmoricola aurantiacus gen. nov., sp. nov., a coccoid member of the family Nocardioidaceae isolated from a marble statue. Int J Syst Evol Microbiol 50, 529-536.

Yoon, J.-H., Lee, C.-H. \& Oh, T.-K. (2005). Aeromicrobium alkaliterrae sp. nov., isolated from an alkaline soil, and emended description of the genus Aeromicrobium. Int J Syst Evol Microbiol 55, 2171-2175. 